\title{
Critiquing the Inter-Disciplinary Literature on Food Fraud
}

\author{
Robert Smith \\ Professor of Enterprise and Innovation \\ The University of the West of Scotland \\ Dumfries, Scotland \\ Louise Manning \\ Senior Lecturer in Food Policy and Management \\ Harper Adams University \\ Shropshire, England \\ Gerard McElwee \\ Professor of Entrepreneurship \\ University of Huddersfield \\ West Yorkshire, England \\ Corresponding Author: Rob Smith, rob.smith@uws.ac.uk
}

\begin{abstract}
The European Horsemeat Scandal of 2013 is a recent manifestation of the problem of 'Food fraud'. It is important from a criminological perspective because it exists at the nexus between organized crime and bad business practice and is a contemporary example of criminalentrepreneurship. From a practical perspective it is a pernicious criminal activity perpetuated by diverse organized-crime-groups, rogue-entrepreneurs and food-industry-insiders. It is a whitecollar-crime committed in the commercial arena, across an extended international food-chain. Geographic and policy boundaries make it difficult to police. Although a high level of awareness of the fraud exists globally, there is a dearth of critical academic research into the phenomenon. The extant literature is spread thinly across various disciplinary silos. This essay by two Business School Scholars and a Food Scientist, discusses the need to develop a more critical, interdisciplinary approach to developing appropriate theoretical frameworks.
\end{abstract}

\section{Keywords: food fraud, food crime, critical criminology, rural criminology, criminal entrepreneurship}




\section{Introduction}

This essay critically explores interconnections between rural and critical criminology, criminal-entrepreneurship and the literature of food fraud to make an incremental contribution to the emerging literature of rural critical criminology as proposed by Dekeseredy and Donnermeyer (2008; 2014) and Donnermeyer, Scott and Barclay (2013). It opens up new ground for rural criminology by incorporating the literature of food fraud as well as contributing to a critical criminology of agriculture and food. Globally there has been a rise in incidences of unproductive and destructive criminal-entrepreneurship (Baumol 1990; Gottschalk 2009) and an increase in the level of organized criminal activity centering upon food fraud. We adopt the United Kingdom (UK) Food Standards Agency (FSA) definition of food fraud. ${ }^{1}$ Food fraud is criminal-entrepreneurship because it involves criminal and legitimate business practices.

Food fraud has been described as 'big business' (Gallagher and Thomas 2010: 352). In the UK food sector alone fraud is valued at around $£ 70$ billion a year to the economy (Shears 2010: 198). It strikes at the core of society by undermining public confidence in the food-chain. Food fraud and food fraudsters do not discriminate between countries and know no boundaries. Yet we do not know the full extent or cost of the fraud (Reynolds 2008). Food fraud (and its adulteration) is a relatively common, exploitative practice fueled by high profit margins (Gallagher and Thomas 2010; Shears 2010).

Food fraud as a collective term encompasses the deliberate and intentional substitution, addition, tampering, or misrepresentation of food, food ingredients, or food packaging; or false or misleading statements made about a product for economic gain (Spink and Moyer 2011a and b). It is carried out intentionally to avoid detection by regulatory bodies or consumers (Grundy et al 2012). The profits from food fraud are comparable to cocaine trafficking, with less risks (Mueller 2007). It is a lucrative, difficult to detect white-collar-crime.

Consideration of corporate and white-collar-crime has been a prime focus of critical criminology (Dekeseredy and Dragiewicz 2011) which traditionally ignored "the rural" (Hogg and Carrington 2002) and the Green-Collar-Criminal (O'Hear 2004; Wolf 2011). Moreover, it often ignores the growing areas of food fraud and food-crime (See Manning and Smith 2014). Rural crime is a fast growing area of scholarly interest because crime manifests itself in rural localities in ways that both conform to and challenge conventional theory and research (Donnermeyer and DeKeseredy 2014). Within this expanding literature, the theme of "green criminology" is of interest too (Lynch 1990; Lynch and Stretesky 2003; South and Beirne 2004; Beirne and South 2006; South et al 2007; Brisman and South 2013; South and Brisman 2013; White 2013; Brisman and South 2014). The theme has been the subject of a stream of special issues (Beirne and South 1998; Ruggiero and South 2009: Mesko et al 2010). A sub theme of eco and environmental crime is also emerging (Walters 2010a; Walters 2010b; Walters 2010c; 
White 2012; Brisman and South 2013; South and Brisman 2013; White 2014). Lymbery and Oakeshott (2014) in their controversial book - "Farmageddon" take a radical criticilist approach to the sustainability of contemporary factory-farming which challenges the idyllic view of farming.

The occurrence of food fraud raises critical questions (or should at least do so) in relation to issues of social, political and economic (in)justice and public health. Food fraud is a heterodox subject that spans many disciplines. Being a protean, criminological topic it is currently situated at the margins of "Critical Criminology" (as an academic discipline) but has huge potential as a field of inquiry for Critical Criminologists. Critical Criminology is a theoretical perspective that concerns itself with structural and societal inequalities (Taylor, Walton and Young 1973). Whilst as a criminal activity food fraud does not fit in with the critical orthodoxy of subject matter associated with Critical Criminology - at its core are issues of injustice central to its founding ideological framework. At present there is no unifying inter-disciplinary literature on food fraud and food-crime. Indeed, the literature is sparse. This article critically reviews the multidisciplinary literature to identify issues of interest to Critical Criminologists. It also identifies boundary-spanning issues to be overcome before such inter-disciplinary research materializes and will start to explore intersecting lines of inquiry.

\section{On the necessity for authoring a Multi-Disciplinary Literature Review}

The literature on food fraud is a fragmented disparate inter-disciplinary one as evidenced by our mapping of the literature illustrated in Figure 1 below. There is a small, fragmented, but growing literature on food fraud located across academic journals associated with food science and the food industry and in criminology journals. The debate however has not been conducted in any detail within the small business or entrepreneurship literatures. This is a crucial issue for developing criminology research from a critical perspective, because there is a need to synthesize and critique this interdisciplinary knowledge base. As far back as 2004, UK food safety professionals warned of the number of serious food offences being carried out by organised criminals including the introduction into the food-chain of meat unfit for human consumption, such as reprocessed chicken sludge, that had been bleached and treated to resemble something palatable. This has led to questions relating to the integrity and sustainability of the food-supplychain in the UK (Pointing and Teinaz 2004). There is thus significant potential for severe harm and injustice to occur resulting from criminal activity so food fraud should be of interest to Critical Criminologists, Rural Criminologists, and for that matter, all criminologists.

Food fraud is a topical subject (Shears 2010: 198). Yet, our main source of up-to-date subject knowledge is from the media and journalistic writings. Food fraudsters are clandestine, 


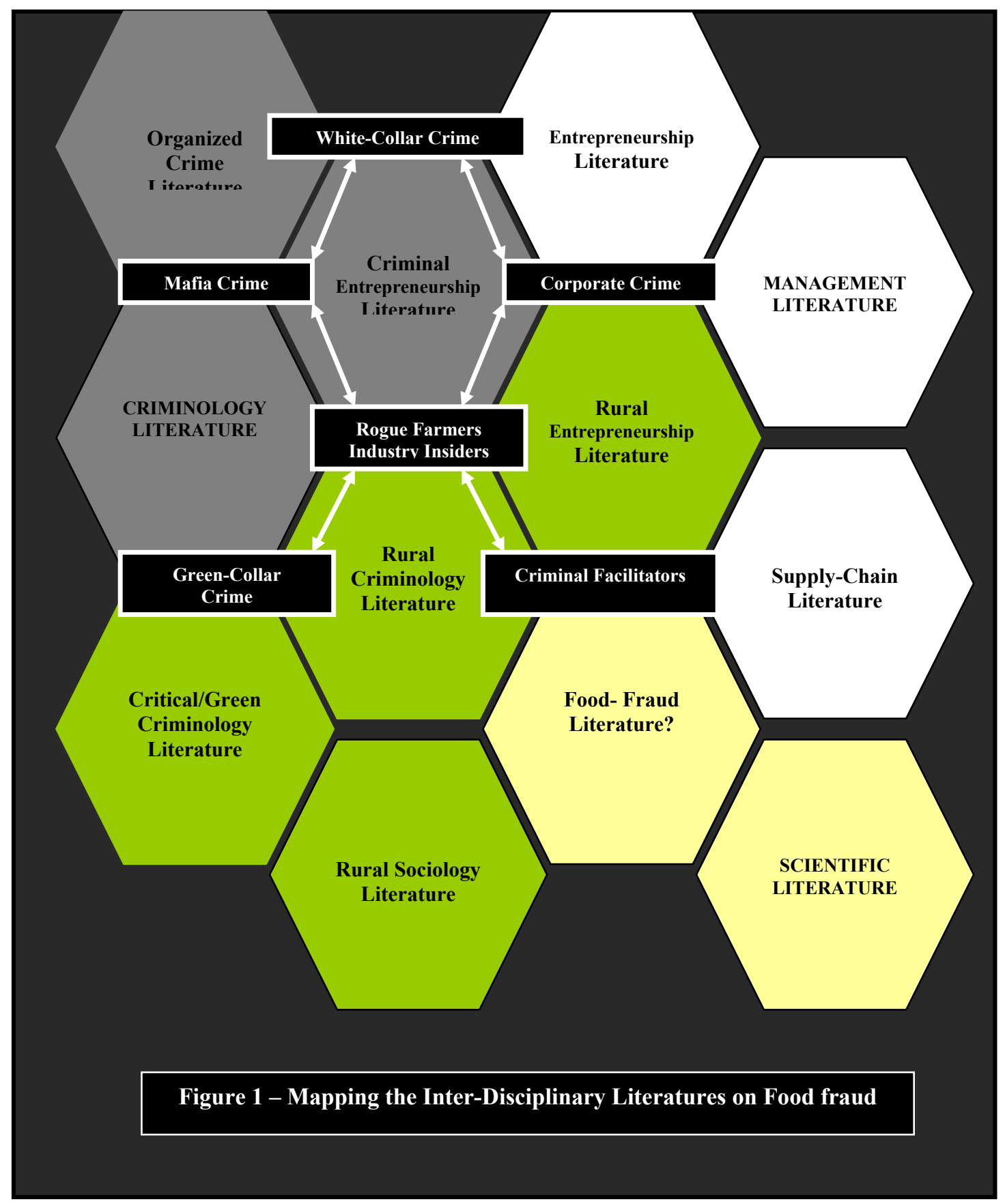

stealthy, and actively seek to avoid detection (Spink 2011) being economically motivated to cheat the consumer. There are a number of ways that food fraud can occur (Spink and Moyer 2011b) including the product being stolen; sold in alternative markets; having fraudulent packaging; an illegitimate product being passed of as legitimate; and counterfeiting. Detecting such offences is difficult and time consuming and relies on good quality intelligence from the industry and general public. Detection of food fraud in meat often requires the scientific analysis of food via sophisticated food DNA techniques. Whilst there may be no food safety risk, in general that a substitution has occurred means there is a high profit margin for the criminals. The 
issue of moral panic over food-safety is also in play (Critcher 2008). Thus it is apparent that there are structural issues that are of interest to Critical Criminologists and Rural Criminologist. This is important because articles outside the discipline of criminology are unlikely to be on their reading lists.

\section{Considering the Scientific literature}

There is a scientific knowledge base for food fraud which must be tempered by knowledge of business practices and law (Shears 2010). This literature tends to deal with technical and evidential issues and seldom strays into criminological debate. The bulk of academic publications on economically motivated adulteration (EMA) are based upon the US work of Spink and colleagues (Spink 2011; Spink and Moyer 2011a and b; Spink 2012; Moore Spink and Lipp 2012; Spink and Moyer 2013; Spink, Moyer, Park, and Heinonen, 2013; Spink, Moyer, Park and Heinonen, 2014) and generally covers structural issues which lead to the practice of fraud. In particular, the issue of fraudulent mislabeling of one type of food as another is a hot topic (for example, the process of labeling horsemeat as prime beef or adulterating beef with cheaper horsemeat or horse protein to inflate the profit). It may well be that the cheaper horsemeat was introduced with the intention of keeping costs low in a highly competitive cost cutting environment within a supply network where the margins at certain points in the supplychain are low. This is of note because the criminological literature seldom considers supply chain issues. The products implicated were "value products" such as own brand burgers, shepherd's pie etc., where the cost of ingredients is closely controlled to meet finished product pricing structures. This issue has to be balanced with media reports that the incident was an organized criminal conspiracy initiated by shadowy Eastern European Mafias. Likewise, issues of commercial value are seldom considered even by uncritical criminologists. Moreover, criminological inquiry is likely to be concentrated on involvement of Mafia and organized crime and not upon business practices.

Some food fraud and mislabeling can occur without vendors' knowledge because of the complicated interactions of food supply-chains/networks when a supplier adulterates the product for financial gain. Where there is no transgression of law, mislabeling is seen as an ethical issue, not a criminological one. However some vendors may have complicity and know the provenance of the product (See Shears 2010: 202, for a discussion and examples of false provenance). Shears argues that inspections, including farm and factory visits, are an essential tool in ensuring the provenance of food within the supply chain. See also Jacquet and Pauly (2008) for a discussion of mislabeling of sea foods and the subject of traceability. There is a pressing need for enforceable global legislation on food labeling which should contain country of origin, date of processing and method used in the harvesting and preparation of the food. Such arguments are not new to Critical Criminologists. 
This is obviously an organised criminal activity preying on the extended global food / supply chain when there is a resource scarcity and thus the potential for greater profits (as is currently the case). This leads to huge economic losses to governments and consumers and has consequences for the eco-environment and public health. Thus traceability is paramount (Schröder 2008) in an age where the global food-chain is becoming increasingly longer with different processing functions being carried out in different countries. Schröder argues for more specific and sensitive testing methods that allow for a better characterization of foodstuffs balanced against consumer protection and fair trade. The issue of supply-chain complexity and the ability for information to flow through that chain is also of concern. For example, Scally (2013) argues that the lengthening of food supply-chains, accompanied by the increased industrialization of the food business, impacts on the food culture of developed countries and that modern food processing lends itself to opportunists seeking to practice fraud on consumers on a truly massive and international scale (Manning and Soon, 2014). Fraud impacts across the globe due to the globalization and consolidation of food procurement. Food fraud cannot be identified merely by following a paper/data based audit trail. Its detection requires state-of-theart scientific analysis (Shears 2010: 208). Random sampling can lead to the detection of fraud and verify the integrity and authenticity of a food source. However, the use of intelligence based assessment can target such sampling to utilise national and local surveillance activities more effectively. It is through routine surveillance sampling that many authenticity issues are uncovered. Thompson (2013) argues that DNA testing can prevent further food fraud scandals, however, the cost of the testing means that this cannot be a routine quality control test.

Although there is clearly a scientific basis and knowledge base for understanding and identifying food fraud, combating it is clearly a criminological concern because the primary motive behind the fraudulent activities of unscrupulous traders and criminals continues to be financial greed (Gallagher and Thomas 2010). Food fraud is a problem that must be tackled by all major stakeholders and consumers underpinned by - “...good investigative techniques, sound methods of detection, sufficient enforcement powers and adequate resources...." (Gallagher and Thomas 2010, 349).

There is a need to develop a more joined up approach to interdicting criminals involved in the extended food-supply-chain. This includes aligning the methods of investigation and detection to encompass the whole supply-chain from consumer complaints about so called "rogue-products" to market surveillance and scientific analysis. Thus cooperation between the food authorities and the police is essential because of the growing tendency for such frauds to escalate into large scale investigations requiring the forensic scrutiny of large volumes of company and business-related documents (Gallagher and Thomas 2010, 351-52).

Despite all the sophisticated developments and analytical techniques, there remains the basic problem of a lack of surveillance resources (Shears 2010: 198). Verifying the description of food in terms of origin and composition is challenging and determining if a foodstuff is 
exactly as described is not an easy task (Primrose, Woolfe and Rollison 2010). In most high profile food fraud cases, criminality is profit oriented (Cheng 2012). Although some food mislabeling may occur accidently, human error should be rare because all legitimate business operators are required by law to adhere to necessary processes and procedures to ensure that their suppliers can be fully verified and that they are at no risk of being duped by being sold adulterated or misdescribed foodstuffs. Everyone along the food chain has a responsibility to prevent harm to the consumer (Gallagher and Thomas 2010, 352). From this overview it is evident that many of the factors in preventing or detecting food fraud are situated outside the criminological domain - necessitating inclusion of knowledge from the scientific sphere in any mitigation activity.

\section{Considering the Criminological literature}

Food-crime is an emerging area of criminological scholarship (Croall 2006; Walters 2007). It is on the rise because of the use of fraudulent marketing practices, and the aggressive trade policies of governments and corporations. Unethical, and illegal, business behaviour in the UK and abroad is increasing. The works of Hazel Croall on food-crime as a type of economic crime and as a particular form of crime suggest that such crimes are less visible and receive less public or academic attention than other areas of white-collar and corporate crime (Croall 1989; 2006; 2009b; 2009c).

There is an increasingly blurred line between illegitimate commercial activities (criminologically associated with corporate or white-collar crime) and illegitimate economies and economic transitions (criminologically related to organized and professional crime) (Croall 2009: 166). The stereotypical image of the food fraudster is of the faceless corporate executive. Yet, Croall argues that our courts are full of routine cases where the accused are small shopkeepers, restaurateurs, market traders and second-hand car salesmen. Often the charges seem trivial such as dirty milk bottles and mouldy food (Croall 1989). Croall asks why corporate figures appear immune from prosecution despite the organised criminal nature of "ShadyOperators" (Sutton and Wild 2005) involved in serious food fraud. Croall argued that while there is growing public concern about a number of food and consumer issues, these continue to have a lower political and governmental profile.

Food fraud occurs in the context of "Cheap Capitalism", characterized by low price, inferior quality of products and degraded social morality and business ethics. Much of the literature in criminological journals concentrates on the law and legal sanctions and the lack of a credible sentencing deterrence with food hygiene legislation been seen as obsessively detailed and impenetrable even to lawyers (Pointing, Teinaz and Shafi 2008). The need for food business operators to determine for themselves their responsibilities to demonstrate they have taken reasonable precautions and that they have exercised all due diligence makes it difficult to identify in a legal prosecution whether an identified deficiency is due to a lack of understanding 
of what is required by the food business operator or criminal intent. The overarching problem with the criminological literature on rural criminology, green criminology and food fraud is that it is seen as a niche area and consequentially there is often very little theoretical development in the material published. It will take time for the chain of theory building to develop from descriptive case studies towards typologies and finally full-blown theory.

\section{Considering the role of organized crime}

One of the major problems of policing and interdicting food fraud is that it covers a wide gamut of criminal activities, types and levels of seriousness. At the lower end of the scale it can involve the complicity of rogue-farmers who knowingly conspire with others to enter adulterated or substituted food into the foodchain for profit, or whom flout food-safety and hygiene regulations. Alternatively, rogue-entrepreneurs/businessmen may appear to operate ostensibly legitimate businesses in the food industry but are knowingly involved and complicit in flouting the laws and regulations for profit (Croall 2005). Then there are corporate offenders who may knowingly or unwittingly commit food fraud (Croall 2005). Corporations and their employees are not immune from behaving criminally in the pursuit of profit. During the 1990s globally it was widely believed that there was a proliferation of cartel-like activity initiated in corporations in the food industry which resulted in a number of injurious conspiracies that operated against small food producers in the UK, France and Europe (Connor 2003). The actions of the corporations were predominantly predatory. It is often argued that collectively such rogues are white-collar-criminals (Sutherland 1947). Crimes of the powerful and in particular middle-class entrepreneurs and professionals who flout the law for profit should be of interest to both Critical Criminologists and Rural Criminologists. However, by designating them as such and subsuming the offenders and their nefarious activities into the category there is a danger that one excuses the seriousness and the predatory criminal nature of this type of fraud. This evidences the need for a critical reappraisal of aspects of white-collar criminality.

One must consider the activities of organized crime groups such as the Italian Mafia, and the Romanian and Polish and other Eastern European Mafia's (Sergei and Lavigne 2012). Such Organized Crime Groups (OCGs) often adopt the appearance and borrowed legitimacy of legitimate businessmen or may use fronts to run their criminal enterprises. Alternatively, they may bribe or threaten business owners, managers or employees to adulterate food products. The problem with dealing with such fraudsters is that they operate from a privileged business position and own properties or lands which gives them an advantage in that the acts are often occurring in secrecy. Again, we see a crossover with the aims of Critical Criminology to expose structural inequalities which allow certain classes of offenders to commit their crimes with impunity. The diverse types of criminal involved in the food fraud chain require diverse policing strategies due to their varying criminal and business modus operandi and business models. There are two classes of food criminal (Smith and Laing 2013): (1) the parasitical type, committed as theft by 
OCGs who target livestock for theft with the intention of passing the resultant meat, illegally into the food chain; and (2) the insider type crime, where owners of abattoirs become involved in the mislabeling or adulteration of their product by adding cheaper and often potentially dangerous alternative meat products into the mix. Often the meat added is condemned as unfit for human consumption. These crimes are committed by unscrupulous entrepreneurs.

This necessitates developing appropriate enforcement strategies for the different types of criminal involved. The traditional organized criminals are usually known to the police and authorities as part of OCGs or Mafias. The rogue-businessman is an individual with criminal inclinations and propensities whom is either targeted by organized crime or are aligned to them. This is important because they have a different modus operandi, modus vivendi and business model and the two types are not mutually inclusive/exclusive. To sell their stolen or appropriated goods, OCGs must form alliances with rogue-entrepreneurs or traders involved in the food industry. Spink and Moyer (2013) also comment on the almost infinite number of types of fraud and fraudsters and identify three areas of threat: (1) from traditional organised crime groups (OCGs); (2) from unscrupulous corporate insiders; and (3) from individual rogue farmers, entrepreneurs and small businessmen.

Spink (collectively) argues that criminology as a discipline provides a framework for assessing food fraud incidents and formulating strategies to reduce the fraud opportunity, but entrepreneurship also offers a fruitful framework for achieving verstehen. There is clearly a need for more critical, joined up research.

A criminal eco-system develops around these practices bringing routine activities theory into play (Felson 2006) whereby criminals are vulnerable in their everyday settings because they develop routines and common practices that make them predictable and thus interdictable. Adopting Felson's approach of identifying events, sequences and settings is helpful in developing forms of food fraud risk assessment. Moreover, when dealing with such individuals there is a tendency to concentrate on the evidential and the criminal (and thus modus operandi) as opposed to the wider holistic picture of how the actors fit into the business models and supplychain-networks adopted. Business modeling is not a practice taught to either criminal investigators, or food supply chain specialists. In food fraud, business angles such as industry characteristics; occupational and employment characteristics; labour supply factors; supplychain-management issues, sub-contracting and business models come into play (Lalani and Metcalfe 2012).

\section{Considering the role of the SME Sector in combating food fraud}

The locus of origin for most food frauds is in the small and medium enterprise sector (SME) with their roots in economic and entrepreneurial activity. Food Industry Entrepreneurs are 
flexible and are often able to quickly react to market changes, and can offer a differentiated product to the consumer with unique selling propositions (Manning \& Smith 2013). In relation to entrepreneurship and enterprise, food (as in its production, distribution and consumption) plays a significant part in the SME and micro-business sectors. This turbulent environment has high levels of competition and low profit margins often in complex and extended food-supply-chains. It is a highly regulated industry by multiple government agencies with food and business legislation prevailing. There are high levels of business turnover and movement of food business operators from one enterprise to another. This has implications for business knowledge, foodsafety risk, and traceability and for criminal opportunities. In harsh economic conditions, and times of austerity, it may be tempting for an entrepreneur to substitute ingredients to undercut competition, for example pork substituted for beef, if it is cheaper. If there is no effective deterrent via an extensive sampling and testing system and a contingent policy of punishment if caught then many otherwise ostensibly honest entrepreneurs may take a risk to increase profits or survive adversity. Nevertheless, there is a dearth of critical research in criminology relating to SME's. Consequentially, the role of predatory criminals in the food-supply-chain remains uncharted. Industry malpractices such as fraud may be driven by the need to compete with other businesses with better economies of scale and to compete with corporate manufacturers, foodservice-companies and retailers operating as oligopolies. Yet, corporate crime in the food industry remains drastically under researched in criminology (Lymbery and Oakeshott 2014).

\section{On the need to develop more theoretical sources of information}

Hazel Croall pioneered food fraud, bringing it into focus over a decade ago by reporting on "The Great Food Racket" - a highly organised trade in food from major stores past its sell-by date sold by various other outlets and market stalls (Croall 1989, 161). Croall (2009a) also reported on the practice of food-laundering whereby condemned meat products considered unfit for human consumption are fed back into the foodchain. She pioneered data-mining of newspapers and journals for salient facts and like a journalist wove these into a cohesive narrative. This brings another overarching issue into focus in that much of the literature on green criminology results from review articles and from documentary research (Scott, 2006) and not from empirical studies. It is quite common for such articles to be critical social commentaries on food fraud, food-crime and environmental issues of concern (and ironically this article is no different). Critical Criminologists, as well as Rural Criminologists, have a duty to report and inform as well as to theorise and develop documentary-styled commentaries to document evidence related to crime trends. Micro-case studies, stories and work examples are used to underpin contemporary incidents of criminal activity to illustrate the points being argued. From an academic perspective this may result from the fact that food fraud is difficult to research because one seldom has access to the perpetrators. Indeed, Professor Hazel Croall successfully used the 'sources of information' device in lieu of a methodological exploration. Documentary Research is a valid investigative technique for securing evidence because it permits 
contemporary media accounts of phenomena to be used to develop a protean literature in areas of emerging academic interest.

Another type of food fraud is the 'Halal Meat Scam' also known as the 'Smokies Trade' (Smith 2004; Pointing and Teinaz 2004; Pointing, Teinaz and Shafi 2008; Tenez and Pointing 2011). These studies highlight structural issues of concern, such as the fact that they are committed by powerful individuals within the farming and business communities, which make the crimes financially lucrative for those involved. It is significant that many food fraudsters are businessmen or rogue farmers (Smith, 2004) who do not fit the typical profile of the urban organised criminal. Clearly there is a need to better understand food fraud and the food industry and to do so we must crossover into the literatures of entrepreneurship and supply chain management. There is also a need to critically overhaul the literature on white-collar criminality to include new developments.

In relation to the Horsemeat Scandal, Premanandh (2013) considers it a wake up call for regulatory authorities globally because it evidences an increase in global incidences of food misdescription and adulteration across the international food trade. Food authenticity and food safety are now of criminological concern. Premanandh discusses the role of regulatory authorities in circumventing the issues relating to meat authenticity. There are numerous science-based technological solutions to combat fraud or accidental mislabeling but how we regulate against predatory entrepreneurial criminals who exploit flaws in the regulations and contaminate the extended foodchain is critical. Collective action by continuous monitoring schemes, along with improved detection methodologies, and stringent regulation on defaulters will minimize or even eliminate authentication problems in future. Nevertheless, scientists and regulators are not aware of the nuances of the debate of concern to the Critical Criminology Community.

There is a growing interest in rural criminology, and green criminology from a critical perspective as evidenced by the recent plethora of edited books on the subject. For example, Croall (in Beirne and South, 2013) considered the role of farmers, small businessmen and corporate offenders as criminal capitalists who exploit the environment and the market place for their financial gain). Croall (2013 in South and Brisman) developed her arguments for the complicity of corporate business in the food industry in creating the circumstances in which the commission of food crime thrives. Croall cited cultural, organizational, and structural reasons such as financial pressures and corporate culture. She uses the evocative term of "criminogenic corporate power" wielded via trade practices, pricing structures and exploitation. Taylor (1999) also critically examined the role of business in market societies in generating and facilitating crime. Such articles make a call for further research into rural criminology. There is also evidence of work being conducted from outside the discipline of criminology. For example, there is an increasing stream of rural research on entrepreneurial crime from business school scholars. For example, consider the following issues: Smith (2011) on Illegal dog-fighting; McElwee, 
Smith and Sommerville (2011) on illegal rural enterprises; Smith and Laing (2013) on alternative perspectives on rural crime; Smith and McElwee (2013) on rogue farmers; Smith (2013) on developing a typology of rural criminals; Smith, Laing and McElwee (2013) on the rise of illicit rural enterprise within the farming industry; Smith and Whiting (2013) on the illegal trade in veterinary medicines; and Smith (2015) on the illegal black fish scandal (2015). These studies are criminological in nature but are published in entrepreneurship, management and rural Studies journals.

\section{Conclusions}

There is a pressing need for studies which inform investigative practice to develop an understanding of criminal-business-models to enable investigations to be carried out more efficiently and effectively in future to a common standard. As a result, it will be possible to interdict and/or disrupt ongoing criminal enterprises using knowledge of their business practices. In combating food fraud we must critically adopt knowledge of food-supply-chains and their interactions, behavioural sciences, business studies and criminology and apply the lessons learned to deter food fraud activity and its perpetrators. Food scientists must adopt and understand basic criminological concepts and adopt an interdisciplinary approach to complex problems in the food industry (see Everstine et al 2013). Politicians, policy makers, investigators and criminologists all hold separate parts of the knowledge base and, in the UK, the Food Standards Agency, local authorities, the police etc hold the practical and experiential knowledge. Collaboration can create a clearer and more robust legal and investigative infrastructure to prevent, deter and detect food fraud.

One of the issues surrounding the horsemeat scandal was the depth of the extended food chains across numerous European countries and involved many big name food brands. This illustrates the scale of criminality involved and the entrepreneurial orientation of the organized criminals and rogue-entrepreneurs involved in the continuing scam. Food fraud has serious health and financial implications for the farming and wider food industry, making it a topic of interest beyond criminology. There are implications relating to how we as a society police food fraud making it necessary to discuss potential solutions to combating food fraud scenarios. These are all potential areas of scholarship for both Critical Criminologists and Rural Criminologists. To restrict the critical inquiry to the literature of criminology would be a mistake. Critical and Rural Criminologists must engage with Critical Management Theorists and Critical Scientists to develop new inter-disciplinary topics of interest.

This article begins the exploration of the interconnections between Entrepreneurship, Rural and Critical Criminology, demonstrating that crime and rurality are constructed from an interdisciplinary knowledge base (albeit it has yet to be properly synthesized). This critique acts as a review and discusses scenarios that target some key social, cultural, and economic forces 
(DeKeseredy and Perry 2006) that propel people into crime within the wider food industry. The issue of food fraud raises critical questions in relation to social, political and economic justice and public health worthy of attention by both Critical and Rural Criminologists. Food fraud is a heterodox subject. It spans many disciplines and sits at the margins of 'Critical Criminology' (as an academic discipline) in that as a criminal activity it does not, at first glance, appear to fit in with the critical orthodoxy of subject matter associated with the topic. Despite there being definitional as well as boundary issues to overcome it does have the potential to become a mainstream thread for Critical Criminological Inquiry. Food-crimes infringe issues of social harm and social justice.

This article begins to explore intersecting lines of inquiry by making a call for inter-disciplinary reach. Opening up Criminology to include business theories as a means of explaining criminal activity is a risky, yet crucial necessity. As Business School Scholars and a Food-Scientist, we the authors have benefited greatly from using a Critical Criminological perspective to underpin our thinking. We believe that this article makes a new contribution because it will be useful to policy makers and as an interdisciplinary teaching case.

There is a need to continue to be critical of mainstream theories and models of rural criminology which perpetuate notions that rural crime is inflicted upon an idyllic rural population solely by urban marauders (Dingwall and Moody 1999: Smith 2010). Rogue farmers, shady-operators, businessmen and industry insiders involved in food fraud challenge prevailing criminological stereotypes. The food industry spans the urban and the rural so in reality criminal stereotypes cannot be expected to conform to ideal typifications. Thus in situating the discourse in the wider structural universe of food industry we are one step closer to understanding foodcrime in terms of its social organization and culture (Donnermeyer and DeKeseredy 2008: 8). It also helps address the neglect of the rural (Donnermeyer 2007).

In developing a more nuanced literature we must encourage and foster a spirit of interdisciplinary collaboration with other criminologists and scholars from outside the discipline. There is a need to conduct more studies on rural and green criminology and to move beyond the descriptive and the use of case studies towards a deeper level of empiricism. We need to listen to and include the voices of farmers, food producers, industry insiders, workers, victims and environmentalists. To develop a critical mass we need more studies per se. We see the role of the Critical Criminological Community as being to highlight the critical areas of criminological concern facing green and rural criminologists so we debate these in our Business School and Scientific Communities. 


\section{Endnotes}

${ }^{1}$ The FSA defines food fraud as "any crime which incorporates any deliberately illegal activity relating to food throughout the food chain"....[and]....."the deliberate placing on the market for financial gain foods that are falsely described or otherwise intended to deceive the consumer". It includes "The substitution and adulteration of foods with cheaper often inferior, ingredients and the sale of foods that may have public health implications, such as foods that are unfit for human consumption or are knowingly contaminated".

\section{References}

Baumol, W.J. (1990). Entrepreneurship: Productive, unproductive, and destructive. The Journal of Political Economy, 98, 893-921, https://doi.org/10.1086/261712

Beirne, P. \& South, N. (2006). (eds.) Issues in Green Criminology: Confronting Harms against Environments, Humanity and Other Animals. Cullompton, UK: Willan Publishing.

Beirne, P., \& South, N. (1998). For a Green Criminology, Theoretical Criminology, 2, 211-233, https://doi.org/10.1177/1362480698002002004

Brisman, A., and South, N. (2013). A green-cultural criminology: An exploratory outline. Crime Media Culture, 9, 115-35, https://doi.org/10.1177/1741659012467026

Brisman, A. and South, N. (2013). Resource wealth, power, crime, and conflict. In R. Walters, D.S.Westerhuis and T. Wyatt (eds.). Emerging Issues in Green Criminology: Exploring Power, Justice and Harm (pp. 57-71). London: Palgrave Macmillan, https://doi.org/10.1057/9781137273994_4

Brisman, A., and South, N. (2014). Green Cultural Criminology: Constructions of Environmental Harm, Consumerism and Resistance to Ecocide. London: Routledge.

Connor, J. M. (2002). The Food and Agricultural Global Cartels of the 1990s. Overview and Update. West Lafayette, Indiana: Purdue University, Department of Agricultural Economics. Staff Paper \#02-4.

Cheng, H. (2012). Cheap Capitalism: A sociological study of food crime in China. British Journal of Criminology, 52, 254-273, https://doi.org/10.1093/bjc/azr078

Critcher, C. (2008). Widening The Focus: Moral Panics as Moral Regulation. British Journal of Criminology, 49, 17-34, https://doi.org/10.1093/bjc/azn040 
Croall, H. (2005). Transnational White Collar Crime. In J. Sheptycki \& A. Wardak (eds.), Transnational and Comparative Criminology (pp. 227-245). London: Glasshouse Press.

Croall, H. (2006). Food Crime. In Beirne, P., \& South, N. (eds.), Issues in Green Criminology: Confronting Harms against Environments, Humanity and Other Animals (pp. 206-229). London: Routledge.

Croall, H. (2009a). Who is the White-Collar Criminal? British Journal of Criminology, 29, 157174, https://doi.org/10.1093/oxfordjournals.bjc.a047813

Croall, H. (2009b). Community safety and economic crime. Criminology and Criminal Justice, 9, 165-185, https://doi.org/10.1177/1748895809102551

Croall, H. (2009c). White collar crime, consumers and victimization. Crime, Law and Social Change. 51, 127-146, https://doi.org/10.1007/s10611-008-9147-z

Croall, H. (2012). Food, crime, harm and regulation: Hazel Croall examines food production and its long standing association with illegality and criminality. Criminal Justice Matters, 90, 16-17, https://doi.org/10.1080/09627251.2012.751218

Croall, H. (2013). Food crime. In South, N., \& Brisman, A (eds.), International Handbook of Green Criminology (pp. 167-183). London: Routledge.

DeKeseredy, W.S., and Dragiewicz. M. (2011). International Handbook of Critical Criminology. London: Routledge.

DeKeseredy, W., and Donnermeyer, J.F. (2008). Towards a Rural Critical Criminology. Southern Rural Sociology, 22, 6-28.

Dingwall, G., and Moody, S.R. (eds.). (1999). Crime and Conflict in the Countryside. Cardiff, Wales: University of Wales Press.

Donnermeyer, J.F. (2007). Locating rural crime: The role of theory. In E. Barclay, J.F. Donnermeyer, J. Scott, and R. Hogg (eds.), Crime in Rural Australia (pp. 15-26). Annandale, AU: Federation Press.

Donnermeyer, J.F. (2014). On expanding the concept of green collar crime. The Critical Criminologist, 22, 2-5. 
Donnermeyer, J.F., and Dekeseredy, W. (2014). Rural Criminology. London: Routledge.

Donnermeyer, J.F., and Dekeseredy, W. (2008). Towards a rural critical criminology. Southern Rural Sociology, 22, 4-28.

Donnermeyer, J.F. Scott, J., and Barclay, E. (2013). How rural criminology informs critical thinking in criminology. International Journal for Crime, Justice and Social Democracy, 2(3), 69-91, https://doi.org/10.5204/ijcjsd.v2i3.122

Everstine, K., Spink, J., and Kennedy, S. (2013). Economically motivated adulteration (EMA) of food: Common characteristics of EMA incidents. Journal of Food Protection, 4, 560735, https://doi.org/10.4315/0362-028x.jfp-12-399

Felson, M. (2006). The ecosystem for organized crime. Helsinki: The European Institute for Crime Prevention and Control, HEUNI 25 th Anniversary Lecture. HEUNI Paper No 26.

Gallagher, M., and Thomas, I. (2010). Food fraud: the deliberate adulteration and misdescription of foodstuffs. European Food and Feed Law Review, 6, 347-353.

Grundy, H.H., Kelly, S.D., Charlton, A.J., Donarski, J.A., Hird, S.J., and Collins, M.J. (2012). Food authenticity and food fraud research: Achievements and emerging issues. Journal of the Association of Public Analysts, 40, 65-68.

Gottschalk, P. (2009). Entrepreneurship and Organised Crime: Entrepreneurs in Illegal Business. Cheltenham: Edward Elgar, https://doi.org/10.4337/9781848447332

Hogg, R., \& Carrington, K. (2002). Critical Criminology: Issues, Debates, Challenges. Devon: Willan Publishing.

Jacquet, J.L. and Pauly, D. (2008). Trade secrets: Renaming and mislabeling of seafood. Marine Policy, 32, 309-318, https://doi.org/10.1016/j.marpol.2007.06.007

Lalani, M., and Metcalfe, H. (2012). Forced Labour in the UK: The Business Angle. Joseph Rowntree Foundation.

Lymbery, P., and Oakeshott, I. (2014). Farmageddon: The True Cost of Cheap Meat. London: Bloomsbury.

Lynch, M. (1990). The Greening of Criminology: A perspective on the 1990s. The Critical Criminologist, 2, 1-4. 
Lynch, M.J., and Stretesky, P.B. (2003). The meaning of green: Contrasting criminological perspectives. Theoretical Criminology, 7, 217-238, https://doi.org/10.1177/1362480603007002414

McElwee, G., Smith, R., and Somerville, P. (2011). Theorising illegal rural enterprise: Is everyone at it? International Journal of Rural Criminology, 1, 39-59.

Manning, L., and Smith, R. (2015). Providing authentic(ated) food: An opportunity-drivenframework for small food companies to engage consumers and protect the integrity of the food-supply-chain. International Journal Entrepreneurship Behaviour \& Research, 16, 97-110, https://doi.org/10.5367/ijei.2015.0180

Mesko, G., South, N. and White, R. (eds.) (2010). Green Criminology, Crime, Law and Social Change. London, Routledge.

Moore, J.C., Spink, J., and Lipp, M. (2012). Development and application of a database on food ingredient fraud and economically motivated adulteration from 1980-2010. Journal of Food Science, 77, 118-126, https://doi.org/10.1111/j.1750-3841.2012.02657.x

Mueller, T. (2007). The New Yorker, August 13, available at: wwww.newyorker.com/reporting/207/08/13/070813fa_fact_mueller.

O’Hear, M.M. (2004). Sentencing the green collar offender: Punishment, culpability and environmental crime. Journal of Criminal Law and Criminology, 95, 133-277, https://doi.org/10.2307/3491383

Pointing, J., and Teinaz, Y. (2004). Halal Meat and Food Crime in the UK. Paper presented for the International Halal Food Seminar, Islamic University, College of Malaysia. September.

Pointing, J. Teinaz, Y., and Shafi, S. (2008). Illegal labeling and sales of Halal meat and food products. The Journal of Criminal Law, 72, 206-213, https://doi.org/10.1350/jcla.2008.72.3.496

Premanandh, J. (2013). Horse meat scandal - A wake-up call for regulatory authorities. Food Control, 34, 568-569, https://doi.org/10.1016/j.foodcont.2013.05.033 
Primrose, S., Woolfe, M., and Rollison, S. (2010). Food forensics: Methods for determining the authenticity of foodstuffs. Trends in Food Science \& Technology, 21, 582-590, https://doi.org/10.1016/j.tifs.2010.09.006

Reynolds, I. (2008). Sharing food fraud intelligence: we're more effective together. Speech presented at the European Food Fraud Conference, Birmingham, 29-30 January. www.food.gov.uk/multimedia/pdfs/foodfraud/speech080/29.pdf.

Ruggiero, V. and South, N. (eds.) (2010). Special Issue on Green Criminology. Critical Criminology, 18.

Scally. G. (2013). Adulteration of food: what it doesn't say on the tin. British Medical Journal, 346, f1463, https://doi.org/10.1136/bmj.f1463

Scott, J. (2006). Documentary Research. London, Sage. https://doi.org/10.4135/9781446261422

Schröder, U. (2008). Challenges in the traceability of seafood. Journal of Consumer Protection and Food Safety, 3, 45-48, https://doi.org/10.1007/s00003-007-0302-8

Shears, P. (2010). Food Fraud - a current issue but an old problem. British Food Journal, 112, 198-213, https://doi.org/10.1108/00070701011018879

Smith, R. (2004). Rural rogues: A case story on the smokies trade. The International Journal of Entrepreneurial Behaviour and Research, 10, 277-294, https://doi.org/10.1108/13552550410544231

Smith, R. (2010). Policing the changing landscape of rural crime: A case study from Scotland. International Journal of Police Science \& Management, 12, 373-387, https://doi.org/10.1350/ijps.2010.12.3.171

Smith, R. (2011). Investigating financial aspects of dog-fighting in the UK: A research note. Journal of Financial Crime, 18, 336-346, https://doi.org/10.1108/13590791111173687

Smith, R. (2013). Developing a working typology of rural criminals: From a UK police intelligence perspective. International Journal of Rural Criminology, 2, 126-145.

Smith, R. (2015). The UK 'Black Fish Scandal' as a case study of criminal entrepreneurship. International Journal of Sociology and Social Policy, 35, 199 - 221, https://doi.org/10.1108/IJSSP-02-2014-0018 
Smith, R., and Laing, A. (2013). Listening to Alternative Perspectives on Rural Crime and Criminality: A Report on the Pilot Study. The Scottish Institute for Policing Research (SIPR) Research Summary 15.

Smith, R., Laing, A., and McElwee. G. (2013). The rise of illicit rural enterprise within the farming industry: A viewpoint. International Journal of Agricultural Management, 2, 185-188, https://doi.org/10.5836/ijam/2013-04-01

Smith, R., and McElwee, G., (2013). Co nfronting social constructions of rural criminality: A case story on 'Illegal Pluriactivity' in the farming community. Sociologia Ruralis, 53, 112-134, https://doi.org/10.1111/j.1467-9523.2012.00580.x

Smith, R., and Whiting, M. (2013). Documenting and investigating the entrepreneurial trade in illegal veterinary medicines in the United Kingdom and Ireland. In C. Henry (ed.), Handbook of Veterinary Business and Enterprise (pp. 59-71). Amsterdam: Elsevier.

South, N. and Brisman A. (eds.) (2013). The Routledge International Handbook of Green Criminology. London: Routledge.

South, N., and Brisman, A. (2013). Critical green criminology, environmental rights and crimes of exploitation. In Simon Winlow and Rowland Atkinson (eds.), New Directions in Crime and Deviancy (pp. 99-1100). London: Routledge.

South, N., Carrabine, E., Cox, P., Lee, M., and Plummer, K. (2007). Criminology: A Sociological Introduction ( $2^{\text {nd }}$ ed.). London: Routledge.

South, N., \& Beirne, P. (eds.) (2004). Issues in Green Criminology. Devon, United Kingdom: Willan Publishing.

Spink, J. (2011). The challenge of intellectual property enforcement for agriculture technology transfers, additives, raw materials, and finished goods against product fraud and counterfeiters. Journal of Intellectual Property Rights, 16, 183-193.

Spink, J. (2012). Defining food fraud and the chemistry of the crime. In W. Ellefson, L. Zach \& D. Sullivan (eds.), Improving Import Food Safety (Chapter 9). London: Wiley-Blackwell, https://doi.org/10.1002/9781118464298.ch9

Spink, J., and Moyer, D.C. (2011a). Defining the public health threat of food fraud. Journal of Food Science, 76, 157-162, https://doi.org/10.1111/j.1750-3841.2011.02417.x 
Spink, J., and Moyer, D.C. (2011b). Backgrounder: Defining the Public Health Threat of Food Fraud, in Research Grants. National Center for Food Protection and Defense (NCFPD). http://www.ncfpd.umn.edu. Minneapolis, MN. 7.

Spink, J., Moyer, D.C. (2013). Understanding and Combating Food Fraud, Food Technology Magazine, 67, 30-35.

Spink, J., Moyer, D.C, Park, H. and Heinonen, J.A (2014). Development of a productcounterfeiting incident cluster tool. Crime Science, 3, 3, https://doi.org/10.1186/s40163014-0003-4

Spink, J., Moyer, D.C, Park, H. and Heinonen, J.A (2013). Defining the types of counterfeiters, counterfeiting and offender organizations. Crime Science, 2, 8, https://doi.org/10.1186/2193-7680-2-8

Sutherland, E.H. (1961). White Collar Crime. New York, Rinehart and Winston.

Sutton. A., \& Wild, R. (1985). Small businesses: White collar villains or victims? International Journal of Sociology of Law, 13, 247-59.

Taylor, I. (1999). Crime in Context: A Critical Criminology of Market Societies. Boulder, Colorado: Westveiw Press.

Taylor, I., Walton, P., \& Young J. (1973). The New Criminology for a Social Theory of Deviance. London: Routledge and Kegan Paul, https://doi.org/10.4324/9780203405284

Teinaz, Y.R., \& Pointing, J. (2011). Obstacles in enforcing food regulations. Paper presented at the First Gulf Conference on Halal Industry and its Services (Proceedings, pp. 24-26). January, Kuwait.

Thompson, F. (2013). What's on your plate. New Scientist, 217 (2904), 6-7, https://doi.org/10.1016/S0262-4079(13)60396-6

Walters, R. (2007). Food crime, regulation and the biotech harvest. European Journal of Criminology, 4, 217-235, https://doi.org/10.1177/1477370807074856

Walters, R. (2010a). Air pollution and eco-crime. In Brookman, F., Bennett, T., Maguire, M., Pierpoint, H. (eds.) Handbook of Crime (pp. 867-884). Devon, United Kingdom: Willan Publishing

Walters, R. (2010b). Eco-Crime and Genetically Modified Food. London: Routledge-Cavendish. 
Walters, R. (2010c). Environmental Crime in Scotland. In Croall, H., Mooney, G.\& Munro, M. (eds.), Criminal Justice in Scotland (pp. 152-174). Devon, United Kingdom: Willan Publishing.

White, R. (2014). Environmental Crime. In R. Atkinson (ed.) Shades of Deviance (pp. 222-225). London: Routledge.

White, R. (2013). Guest Editor's Introduction, Green Criminology issue. CRIMSOC: The Journal of Social Criminology, Autumn, 7-9.

White, R. (2012). Land theft and rural eco-Crime, International Journal of Rural Criminology, 1, 203-217.

Wolf, B. (2011). Green-collar crime: Environmental crime and justice in the sociological perspective. Sociology Compass, 5, 499-511, https://doi.org/10.1111/j.17519020.2011.00381.x 